Far Eastern Entomologist

\author{
\begin{tabular}{lll}
\hline Number 364: 6-9 & ISSN 1026-051X & August 2018 \\
\hline
\end{tabular} \\ https://doi.org/10.25221/fee.364.2 \\ http/urn:lsid:zoobank.org:pub:75FCBB15-0678-46DB-844E-93459F4910D1

\section{FIRST RECORD OF HELICTES FABULARIS ROSSEM, 1987 (HYMENOPTERA: ICHNEUMONIDAE) FROM IRAN} \\ H. Darvishnia ${ }^{1)}$, S. Sadeghi ${ }^{1)}$, A. Mohammadi-Khoramabadi ${ }^{2}$, \\ H. R. Esmaeili ${ }^{1, *)}$ \\ 1) Zoology Section, Department of Biology, College of Sciences, Shiraz University, \\ Shiraz 71454, Iran. *Corresponding author, E-mail: hresmaeili22@gmail.com \\ 2) Department of Plant Production, College of Agriculture and Natural Resources of \\ Darab, Shiraz University 74811-96711, Iran.
}

Summary. Helictes fabularis Rossem, 1987 (Ichneumonidae: Orthocentrinae) is reported for the first time from Iran. The distribution of this species is extended toward the southern boundaries of the Palaearctic region. Helictes fabularis is considered as a cave visitor species in Tayegeh Cave where it spends its overwintering stage.

Key words: ichneumonid wasp, fauna, new record, cave, overwinter, Ilam province, Iran.

Х. Дарвишния, С. Садехи, А. Мохаммади-Хорамабади, Х. Р. Эсмайли. Первое указание Helictes fabularis Rossem, 1987 (Hymenoptera: Ichneumonidae) из Ирана // Дальневосточный энтомолог. 2018. N 364. C. 6-9.

Резюме. Впервые для Ирана приводится Helictes fabularis Rossem, 1987 (Ichneumonidae: Orthocentrinae). Ареал этого вида расширен до южных границ Палеарктики. Этот вид является временным обитателем пещер, где он находит подходящие условия для зимовки.

\title{
INTRODUCTION
}

The relatively stable conditions of caves, such as humidity and minimal variation of temperature, provide a suitable place for different groups of animals for overwintering, exploiting food, reproduction, hiding to escape predators, and avoiding extreme temperatures. Thus, the unique environment of caves can be considered as a natural laboratory for biological studies (Romero, 2009). Many invertebrates, especially arthropods, comprise cave-dwelling taxa in different parts of caves. Although there is no report of cave-dwelling species of hymenopterans, some species regularly exist in caves (Novak et al., 2010) and use such stable environments to spend a short or long period of their life cycle in them (Moldovan, 2004). Some species of the family Ichneumonidae (Hymenoptera) inhabit caves to pass their overwintering phase and are known as trogloxene or cave visitors (Hamilton-Smith, 1967). Recently, a trogloxene ichneumonid wasp (Exephanes tauricus) has been reported from the Bare-zard Cave in the west of Iran (Darvishnia et al., 2018). 
Helictes fabularis has not already been listed in the Hymenoptera fauna of Iran (Ghahari \& Jussila, 2010; Barahoei et al., 2012; Mohammadi-Khoramabadi \& Talebi, 2013; Sarafi et al., 2015; Ghafouri Moghaddam et al., 2016; Ghahari \& Jussila, 2016; Mohammadi-Khoramabadi et al., 2016; Mohebban et al., 2016; Mohammadi-Khoramabadi \& Talebi, 2018). This species was found during a field trip to Tayegeh Cave in the spring of 2016 from its twilight zone in Ilam province, west of Iran (Map 1). The specimen was collected using a sweep net. At the time of collecting, the air temperature, humidity, and $\mathrm{CO}_{2}$ concentration $(\mathrm{ppm})$ in the twilight zone were $20^{\circ} \mathrm{C}, 13.5 \%$, and $1880 \mathrm{ppm}$, respectively. The identified specimen was deposited in the Zoological Museum and Collection of the Biology Department, Shiraz University (ZMCBSU), Shiraz, Iran.

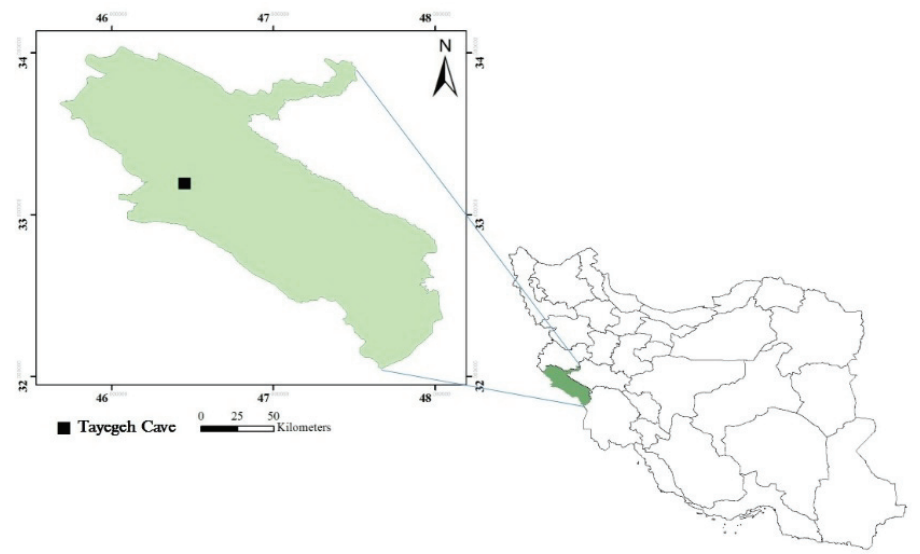

Map 1. Location of the Tayegeh Cave (black square) in Ilam Province of Iran.

\section{NEW RECORD}

\section{Helictes fabularis Rossem, 1987}

Figs 1-5

MATERIAL. Iran: Ilam Province, Malekshahi County, Tayegeh Cave, 1239 m, 28.III 2016, 1 ㅇ (ZM-CBSU Hym. 110), leg. H. Darvishnia.

FEMALE. Detailed description of the female specimen of $H$. fabularis is provided by Humala (2008). The main morphological characteristics of $H$. fabularis are as follows: body length $5.5 \mathrm{~mm}$ (Fig. 1); face and clypeus convex, apical margin of clypeus truncate (Fig. 4), antennae with 28 flagellomeres, first flagellomere $7 \mathrm{x}$ as long as wide, OOL (ocular-ocellus length) as long as $0.8 \mathrm{x}$ POL (postocellar length); mesosoma with epomia present (Fig. 2), epicnemial carina not interrupted, fore wing without an areolet, vein $2 \mathrm{rs}-\mathrm{m}$ short, vein $2 \mathrm{~m}$-cu with two bullae, hind wing with nervellus intercepted below the middle, vein discoidella unpigmented, propodeum with posterior transverse carina well developed as a crest, legs long and slender, hind coxa elongate, hind femur 10x as long as wide, hind basitarsus about $0.31 \mathrm{x}$ as long as hind tibia; metasoma with first metasomal segment 2.3 as long as apical width (Fig. 3); first tergite and sternite fused; apical margin of tergite II, main parts of tergite III and basal part of tergite IV yellowish brown; ovipositor hardly surpasses tip of abdomen; ovipositor sheath apically widened and truncate (Fig. 5). 
DISTRIBUTION. Iran (new record). - Canary Islands, Finland, Kazakhstan, Kyrgyzstan, Lithuania, Poland, NW Russia, Sweden (Yu et al., 2012; Humala, 2015).

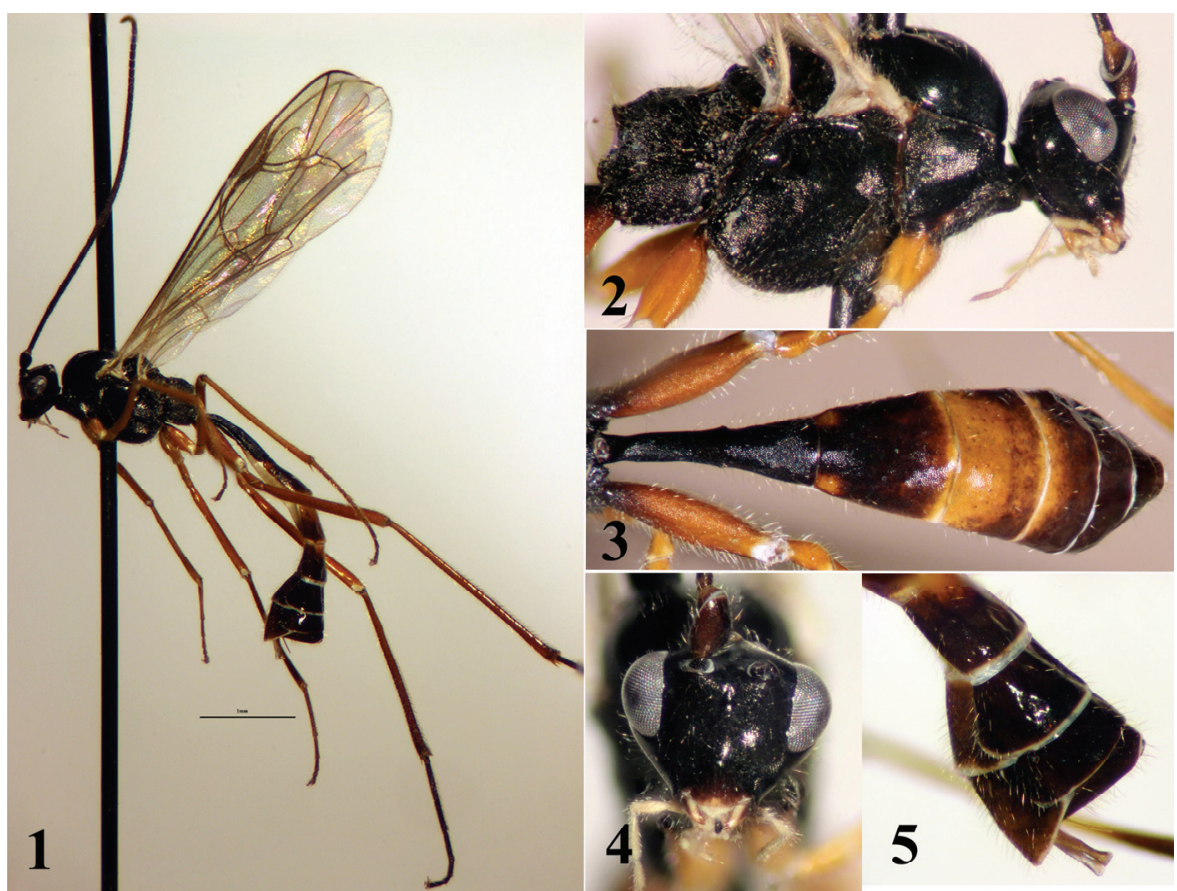

Figs 1-5. Female of Helictes fabularis. 1 - habitus, lateral view; 2 - mesosoma, lateral view; 3 - metasomal tergites, dorsal view; 4 - head, frontal view; 5 - apex of abdomen with ovipositor, lateral view.

\section{DISCUSSION}

The hymenopterans fauna of Iran is particularly diverse of which ichneumonid wasps are mainly not cave-dwellers. By reporting Helictes fabularis, the number of cave visitors from the family Ichneumonidae increases to two species. They occupy caves for hibernating based on the collecting date. The rate at which species are added to the list of the Iranian fauna would suggest that there remain more to be discovered and more samplings will provide a more complete picture of the cave fauna of this family in Iran.

\section{ACKNOWLEDGEMENTS}

We gratefully appreciate Meysam Dashan and Amir Darvishnia for their help in the cave collecting work and Shiraz University for financial support. Our work was approved by the Ethics Committee of Biology Department (ECBD-SU-9231443).

\section{REFERENCES}

Barahoei, H., Rakhshani, E. \& Riedel, M. 2012. A checklist of Ichneumonidae (Hymenoptera: Ichneumonidea) from Iran. Iranian Journal of Animal Biosystematics, 8(2): 83-132. 
Darvishnia, H., Esmaeili, H.R., Sadeghi, S., Riedel, M. \& Mohammadi-Khoramabadi, A. 2018. Exephanes tauricus Hinz, 2000 (Hym.: Ichneumonidae): a new record to Iranian cave fauna. Biharean Biologist, 12(1): 51-52.

Ghafouri Moghaddam, M., Mokhtari, A., Barahoei, H., Amirinasab, N. \& Rakhshani, E. 2016. A survey on the fauna of Ichneumonidae (Hymenoptera, Ichneumonoidea) associated with grasslands of Ardabil, and key to species of Homotropus Foerster, 1869 from Iran. Journal of Insect Biodiversity and Systematics, 2: 103-120.

Ghahari, H. \& Jussila, R. 2010. A contribution to the Ichneumon wasps (Hymenoptera: Ichneumonidae) from Golestan National Park and vicinity, Northeastern Iran. Linzer biologische Beitrage, 42: 1379-1384.

Ghahari, H. \& Jussila, R. 2016. Contribution to the knowledge of the fauna of Ichneumonidae (Hymenoptera: Ichneumonoidea) from Iran. Beiträge zur Entomologie, 66: 119-124.

Hamilton-Smith, E. 1967. The arthropoda of Australian caves. Australian Journal of Entomology, 6: 103-118.

Humala, A.E. 2008. New species of Orthocentrinae (Hymenoptera: Ichneumonidae) from Finland. Entomologica Fennica, 19 (2): 94-104.

Humala, A.E. 2015. Orthocentrinae (Hymenoptera, Ichneumonidae) species new to the fauna of Norway. Norwegian Journal of Entomology, 62: 1-8.

Mohammadi-Khoramabadi, A. \& Talebi, A.A. 2013. A study of the genus Orthocentrus (Hymenoptera: Ichneumonidae, Orthocentrinae) in Gilan and Tehran provinces of Iran, with first records of seven species and one subspecies. Applied Entomology and Phytopathology, 80: 29-39.

Mohammadi-Khoramabadi, A., Hesami, S. \& Shafiei, S. 2016. A contribution to the knowledge of the fauna of Ichneumonidae in Rafsanjan county of Kerman province, Iran. Entomofauna, 37: 453-468.

Mohammadi-Khoramabadi, A. \& Talebi, A.A. 2018. Study of three genera of the Orthocentrus genus-group (Hymenoptera: Ichneumonidae, Orthocentrinae) in northern Iran. Journal of Entomological Society of Iran, 37: 441-460.

Mohebban, S., Barahoei, H., Takalloozadeh, H. M., Madjdzadeh, S. M. \& Riedel, M. 2016, A survey of the Ichneumonidae (Hymenoptera, Ichneumonoidea) of Kerman province, south-east Iran. Journal of Insect Biodiversity and Systematics, 2: 419-437.

Moldovan, O. 2004. Biodiversity in terrestrial cave habitats. P. 295-299. In: Gunn, J. (Ed.) Encyclopedia of Caves and Karst Science. Taylor \& Francis Books, New York.

Novak, T, Thirionm, C. \& Janžekovič, F. 2010. Hypogean ecophase of three hymenopteran species in Central European caves. Italian Journal of Zoology, 77(4): 469-475.

Romero, A. 2009. Cave Biology (Life in Darkness). Cambridge University Press, New York. $291 \mathrm{pp}$.

Sarafi, T., Barahoei, H., Madjdzadeh, S.M. \& Askari, M. 2015. A contribution to the knowledge of the Ichneumonidae (Hym.: Ichneumonoidea) from Neyriz county of Fars province, Iran. Journal of Crop Protection, 4: 643-654.

Yu, D.S., Van Achterberg, K. \& Horstmann, K. 2012. World Ichneumonoidae 2011. Taxonomy, Biology, Morphology and Distribution. Available from: http://www.taxapad.com (Accessed: 20 May 2018). 